\title{
WSPÓŁCZESNE DIALOGI POLITYCZNE. WPROWADZENIE
}

\begin{abstract}
$\mathrm{D}$ ialog stał się dla współczesności pojęciem nieodzownym, jakby na poły był immanencja a na poły droga ratunku. Punktem wyjścia i dojścia. Koniecznościa podyktowana pluralizmem i jedynym sposobem na godną egzystencję. Tak więc jest obecny w kulturze nowoczesnej można by rzec ex definitione, jednocześnie będąc jeszcze odległym horyzontem. Horyzontem, do którego powinniśmy dotrzeć.

Filozofia znała dialog właściwie od swych poczattów. Starożytna Grecja posługuje się dialektyka, jako metoda dochodzenia do prawdy. Zestawia przeciwstawne poglądy, zadaje pytania, daje odpowiedzi i w ten sposób osiaga swój cel - mądrość. Dialogujący Sokrates prowadzi swych rozmówców w objęcia prawdy.

Podobnie średniowiecze. Dialektyka spełnia tu właściwie tożsame funkcje.

Jednak dwudziesty wiek zmienia to podejście do dialogu. Przestaje on być metodą filozofowania a staje się samą filozofią. To znaczace przejście dokonuje się za sprawą filozofii dialogu. „Ta nowa filozofia wskazała, że prawdziwe odkrycie naszego Ja leży w spotkaniu $z$ niezrozumiałym, z Innym. Stanowiła ona próbę włączenia do struktur myślenia innych treści poza poznawczymi i metafizycznymi, i budowania dialogu nie na poszukiwaniu jedności i wspólnych prawd, lecz na aksjologicznym doświadczaniu inności. Filozofia ta uczyła też, że nic bardziej nie stoi na przeszkodzie dialogu $z$ innym niż pretensja do jego rozumienia bez niego" "1. Tak więc dialog przestaje być środkiem a staje się
\end{abstract}

${ }_{1}$ M. Szulakiewicz, Myślenie dialogiczne w poszukiwaniu nowej filozofii pierwszej, w: Dialog w kulturze, M. Szulakiewicz, Z. Karpus (red.), Wydawnictwo UMK, Toruń 2003, s. 44. 
celem. Filozofia ta rzuca też nowe światło na „pozafilozoficzne” znaczenie owego słowa. Wszak powszechnie mniemanie wiąże dialog właśnie ze wspólnymi celami, do których powinien prowadzić.

Nietrudno również zauważyć, iż staje się on wręcz nierozerwalnie złączony z koncepcją i społeczeństwem liberalnym. Postulowana przez liberalizm idea proceduralnej sprawiedliwości może być (jak się wydaje, całkiem słusznie) traktowana jako ,jedyna droga odnalezienia minimum jedności w pluralistycznym świecie kultury zachodniej, gdzie próżno oczekiwać filozoficznego rozwiązania konfliktów między odmiennymi doktrynami światopoglądowymi”’" Myśl liberalna głosi wręcz konieczność istnienia filozoficznych czy światopoglądowych odrębności. Pluralizm staje $w$ parze $z$ wolnościa. Negacja owej różnorodności jest zamachem na priorytetową kategorię liberalną, jaką jest właśnie owa wolność. Jednocześnie w obliczu takiej (pozytywnej dla liberalizmu) fragmentaryzacji ideowej, dialog jawi się jako jedyny sposób na efektywną politykę.

W skali międzynarodowej jest on pojęciem arcypopularnym. Szczególnie aurę taką tworzy koncepcja zderzenia cywilizacji ${ }^{3}$. Z drugiej zaś strony można wskazać szereg monologów lub dialogów będących w swej istocie jedynie mimikra i zawierajaccych implicite relacje dominacji. Sytuacja w Czeczenii czy druga operacja w Iraku nolens volens zmuszaja nas do refleksji nad dialogiem, jako metoda układania stosunków międzynarodowych.

Niezwykle drażliwą kwestia jest dialog w religii. Mamy więc ruch ekumeniczny, ale i oskarżenia o prozelityzm. Możemy być braćmi w wierze, ale i ofiarami dżihadu. Pojawiaja się w związku z tym poważne pytania. Czy możliwy jest dialog między religiami, które mają obowiązek głoszenia własnej wiary, które znaja prawdę, których Bóg jest tym Jedynym? „Chrystus jest pierwszym nauczycielem, który wypowiedział wyraźnie i mocno przykazał swoim uczniom wypełniać uniwersalistyczne wezwanie: Idac tedy nauczajcie wszystkie narody..." ${ }^{\prime 4}$. Czy wobec tego może dojść do prawdziwego dialogu w przypadku religii monoteistycznych? Odpowiedź nie może być jednoznaczna.

Oto współczesność staje się czasem dialogu. Z drugiej strony potrzeba owego dialogu wciąż rośnie. Dostrzegamy w nim sposób na współistnienie, ostoję wolności czy metodę politykowania. Jednocześnie

2 A. Szahaj, Jednostka czy wspólnota? Spór liberatón z komunitarystami a „sprawa polska”, ALETHEIA, Warszawa 2000, s. 58-9.

${ }^{3}$ S. P. Huntington, Zderzenie Cywilizacji, Muza, Warszawa 1998.

4 A. Grzegorczyk, Wspólnota, w: Indywidualizm, wspólnotowość, polityka, A. Szahaj, M. N. Jakubowski, K. Abriszewski (red.), Wydawnictwo UMK, Torun 2002, s. 22. 
pojawiają się niebezpieczeństwa i pytania. Od sprostania im może zależeć los naszej cywilizacji. Czy rzeczywiście możemy mówić o dialogu w polityce? Czym właściwie jest ów dialog? A przede wszystkim czy stanowi on ratunek przed czymkolwiek? Może sytuacja wygląda odwrotnie? Może czai się tu pewne niebezpieczeństwo? „Jest to traktowanie dialogu jako miejsca i sposobu odkrywania wartości, prawd i włączenia dialogu w problematykę uniwersalistyczna. Tu tkwi jednak jakiś fałsz, a nawet coś w rodzaju świętokradztwa, gdy to, co najważniejsze chce się uzależniać od porozumień i ugody"

Jakkolwiek jednak dialog zakłada rozmowę i konieczność wysłuchania Drugiego. Tak więc: „Kto ma uszy do słuchania, niechaj słucha".

5 Cytat pochodzi z noty od redaktorów zamieszczonej w: Dialog $w$ kulturze, M. Szulakiewicz, Z. Karpus (red.) Wydawnictwo UMK, Toruń 2003, s. 12.

${ }^{6} \mathrm{Mk}$ 4, 9: Pismo Święte Nowego Testamentu w opracowaniu Zespołu Biblistów Polskich z inicjatywy Benedyktynów Tynieckich, Płockie Wydawnictwo Diecezjalne, Płock 1988. 